\title{
I Varchi della memoria. La documentazione dei portali del villaggio Rehovë (Albania)
}

Giulia Lazzari

\section{Abstract}

Nel Sud-Est dell'Albania, alle pendici del Monte Gramoz su cui si attesta il confine con il Nord della Grecia, sorge il villaggio rurale di Rehovë. Come spesso accade, è nel cuore delle regioni più remote che è possibile ritrovare le radici di una civiltà, spesso affidate a testimonianze materiali in apparenza poco significative. A Rehovë ignoti scalpellini hanno realizzato l'intero villaggio utilizzando la pietra calcarea locale; le case a due piani sono collocate allinterno di muri di cinta quadrangolari che, assieme ai loro portali, caratterizzano la struttura urbana dell'insediamento. Nel 2019 al CHMLab del DIDA è stata affidata la documentazione morfometrica e cromatica di questi manufatti finalizzata alla loro conservazione.

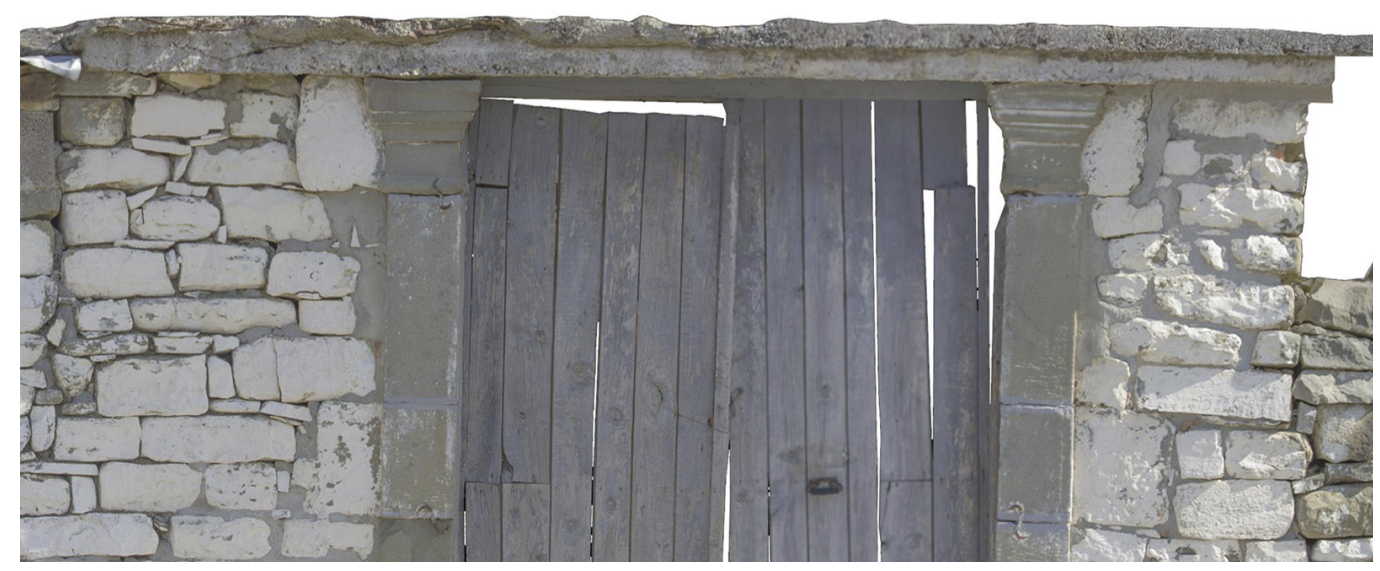




\section{Introduzione}

La realizzazione della campagna di rilievo svolta dal CHMLab (Cultural Heritage Management Lab) del DIDA (Dipartimento di Architettura dell'Università degli Studi di Firenze) muove le sue ragioni dall'interesse mostrato dal Ministero della Cultura della Repubblica Albanese verso gli insediamenti minori, oggetto dal 2017 di una estesa indagine storico-documentale [I]. Nel gennaio dello stesso anno Rehovë è stata insignita del titolo di "centro di rilevanza storica" e un anno più tardi, unitamente all'Università Cattolica di Nostra Signora del Buon Consiglio di Tirana, lo stesso Ministero ha richiesto all'équipe [2] guidata dal prof. Alessandro Merlo (docente presso la stessa Università) di rilevare i sessantotto portali presenti nel villaggio. La finalità dell'operazione è quella di documentare i manufatti per preservarne i caratteri architettonici originari che, nel loro insieme, qualificano il piccolo centro [3]. Già nel 2016 Mirela Kumbaro, ex Ministro della Cultura, aveva messo in evidenza il ruolo strategico di Rehovë all'interno delle politiche di sviluppo del turismo nella regione di Kolonjë, proponendo il percorso denominato The Routes of Gates [4].

La documentazione ottenuta dalla campagna di rilevamento è servita, oltre che a delineare la consistenza geometrico-dimensionale e l'aspetto cromatico dei portali oggetto di studio in vista della definizione di linee guida per il loro restauro, a sensibilizzare la comunità locale sulle problematiche legate al mantenimento e alla conservazione dei propri beni architettonici e artistici.

Fig. I. Porta Gjergji R. Qirjadi. Esempio di scheda contenente piante, prospetti, sezioni e foto di dettaglio.
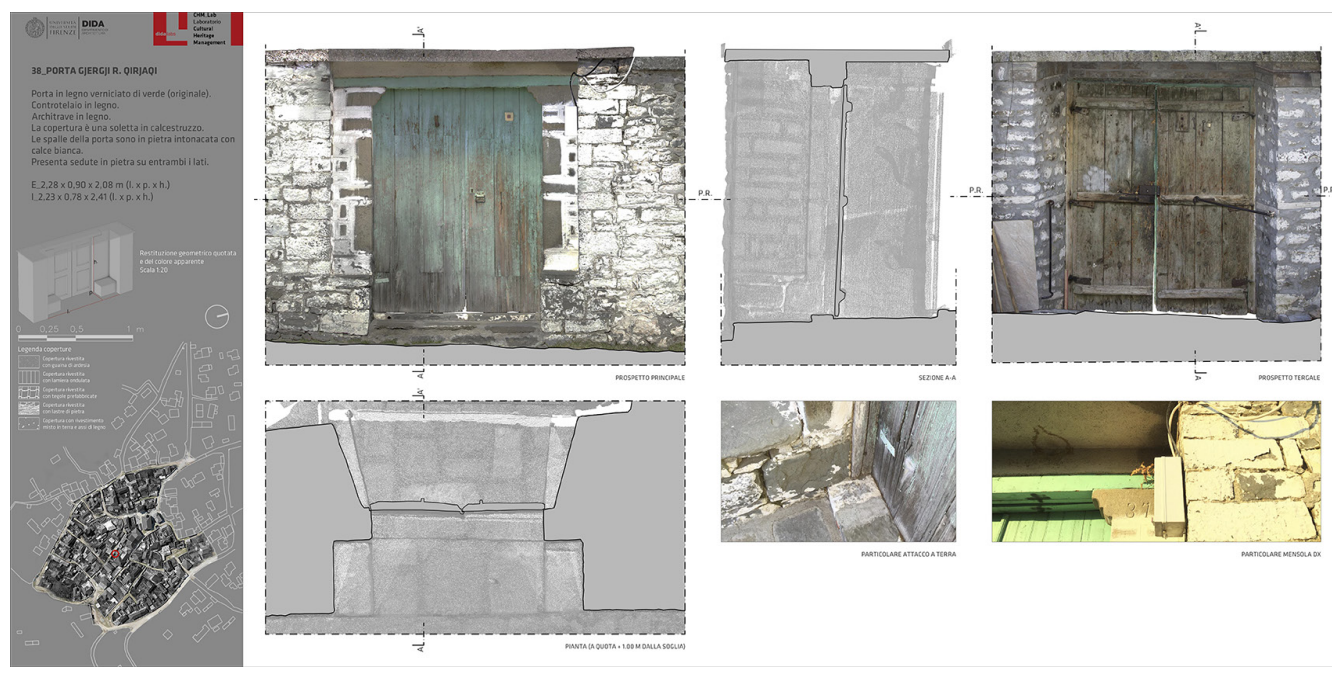

\section{Il villaggio di Rehovë}

Le coste del Mediterraneo sono la culla di civiltà millenarie la cui prosperità è dovuta in gran parte alla possibilità di viaggiare via mare, che ha consentito loro di intessere nel corso dei secoli reti economiche e culturali che hanno influenzato reciprocamente anche la forma dell'abitare [5].

Nel caso specifico dei Balcani, l'avvicendarsi sulle sue coste di due culture diverse tra loro come quella greco-romana e quella turca ha fatto sì che tutt'oggi siano presenti sul territorio entrambi i loro archetipi abitativi [6]: la 'domus', che accoglie negli ambienti domestici il focolare di Hestia [7], e la 'casa corte', in cui gli ambienti distribuiti attorno ad uno spazio centrale sono distinti tra uomini e donne.

II sistema urbano della cittadina di Rehovë è costituito da recinti murari che definiscono i cortili quadrangolari (buona parte dei quali presentano dimensioni simili di 8×6 metri) antistanti le abitazioni, interrotti solo dalla presenza di portali in pietra, che consentono non solo 
il passaggio dall'ambiente pubblico a quello privato, ma costituiscono dei veri e propri luoghi di relazione coperti e in ombra. Oltrepassare un portale aveva qui, fino ad un recente passato, un valore rituale; varcare la soglia significava entrare in contatto con un micromondo a sé, del quale si accettavano le regole.

Nel mondo globale, "le influenze sociali ed economiche della contemporaneità hanno modificato il modello antropocentrico classico della famiglia patriarcale determinando dei cambiamenti nei luoghi specifici dell'abitare: i limiti si perdono e i confini interno/esterno, pubblico/privato, diventano meno netti" [8].

Nella concezione della casa occidentale è stata da tempo abbandonata la netta distinzione tra interno ed esterno. Giò Ponti già nel 1928, ad esempio, così descriveva la casa italiana: "nella casa all'italiana non vi è grande distinzione di architettura fra esterno ed interno: altrove vi è addirittura separazione di forme e di materiali: da noi l'architettura di fuori penetra nell'interno e non tralascia di usare né la pietra né gli intonaci né l'affresco; essa nei vestiboli e nelle gallerie, nelle stanze e nelle scale, con archi, nicchie, volte e con colonne regola e ordina in spaziose misure gli ambienti per la nostra vita. Dall'interno la casa all'italiana riesce all'aperto con i suoi portici e le sue terrazze, con le pergole e le verande, con le logge ed i balconi, le altane e i belvederi, invenzioni tutte confortevolissime per l'abitazione serena e tanto italiane che in ogni lingua sono chiamate con i nomi di quil" [9].

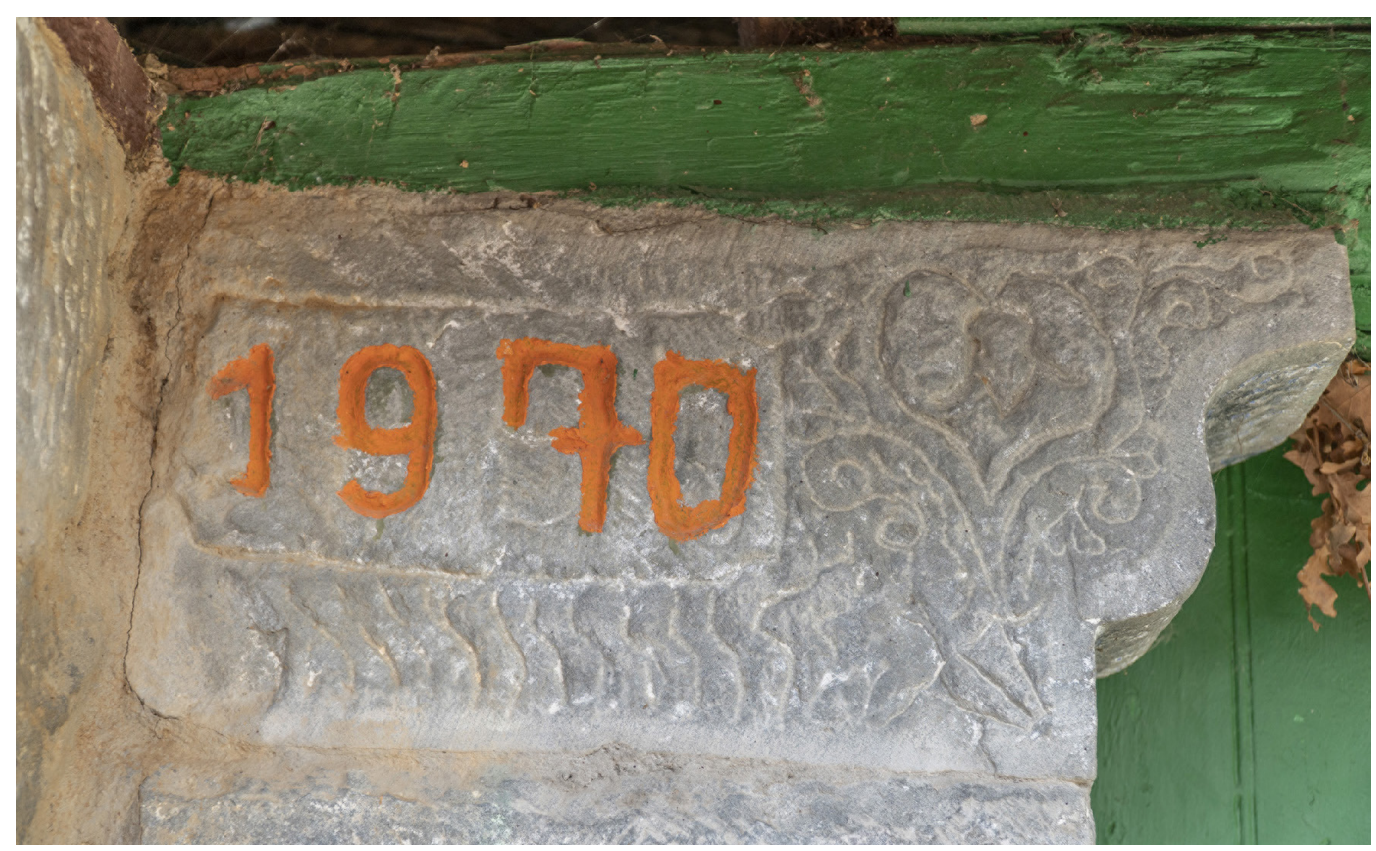

\section{Rilevamento e restituzione dei dati}

La campagna di rilevamento realizzato nel marzo 2019 ha consentito di acquisire un gran numero di informazioni geometriche e cromatiche relative ai sessantotto portali presenti nel villaggio di Rehovë.

Le operazioni di misura sono state condotte mediante l'utilizzo di sensori digitali sia attivi che passivi: le point cloud [ I0], generate da due laser scanner [ I I], hanno permesso la realizzazione di nuvole di punti dense $\left(139 \times 10^{7}\right.$ punti), in grado di descrivere compiutamente la morfologia non solo degli accessi, ma anche delle strade del villaggio, mentre le texture del colore apparente, desunte mediante la fotogrammetria [12], hanno consentito di realizzare i fotopiani dei fronti mettendone in evidenza l'apparato decorativo. 
Fig. 3. Architrave ligneo poggiante su mensola lapidea.

Fig. 4. Manto di copertura in lastre di pietra.
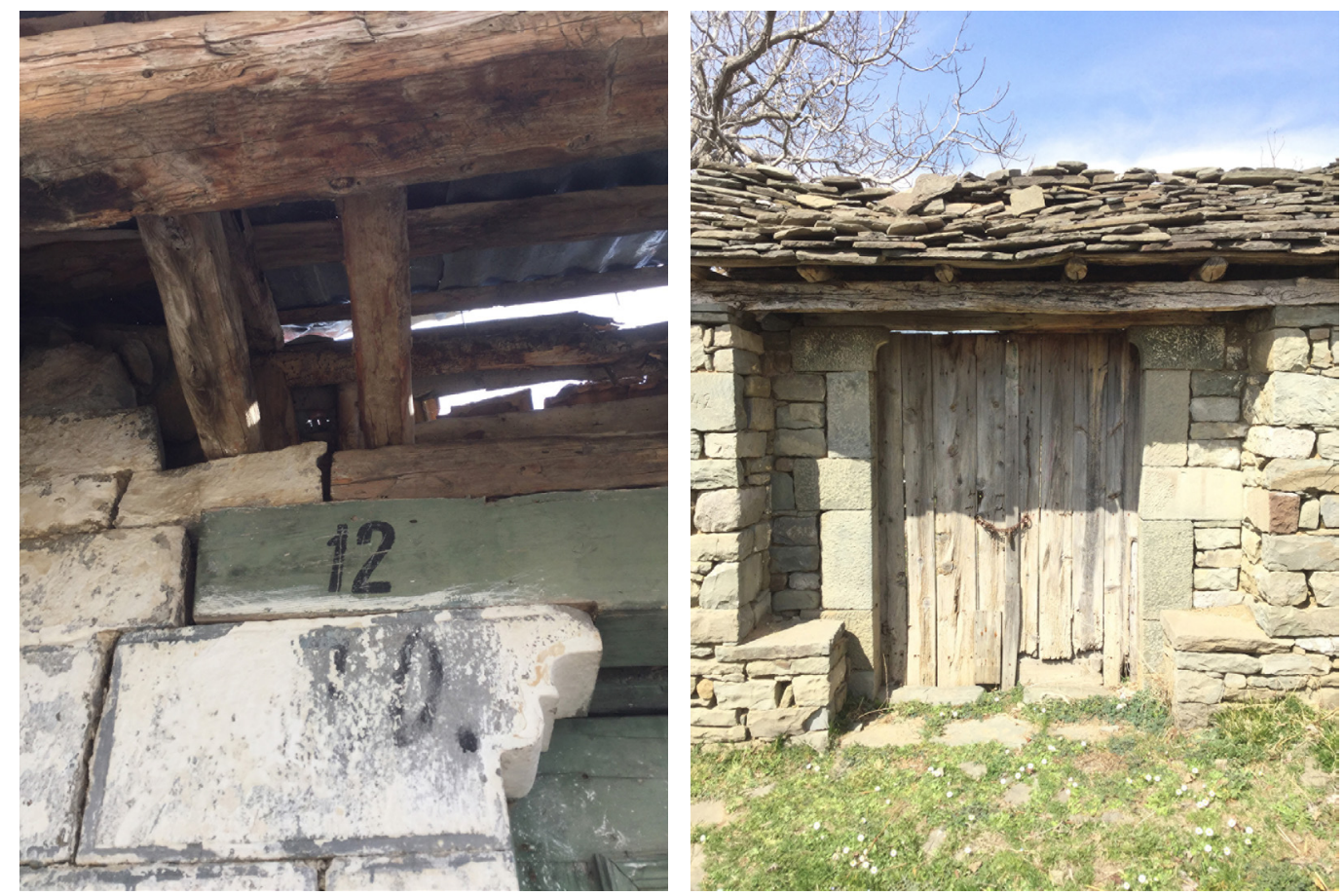

Con il fine di georeferenziare i portali all'interno del tessuto edilizio, questi sono stati collegati tra loro mediante una serie di scansioni intermedie, ottenendo così un modello $3 \mathrm{D}$ del sistema viario dell'intero villaggio con cui è stato possibile, in un secondo momento, scalare e rototraslare il modello fotogrammetrico desunto dalle immagini acquisite sia da terra che dal volo del drone.

Successivamente è stata prodotta una scheda [13] di ciascun bene, che comprende sia le sezioni orizzontali che quelle verticali, i prospetti con le informazioni del colore apparente (fig. I), le dimensioni principali e un breve testo che descrive i manufatti ponendo in evidenza le caratteristiche principali.

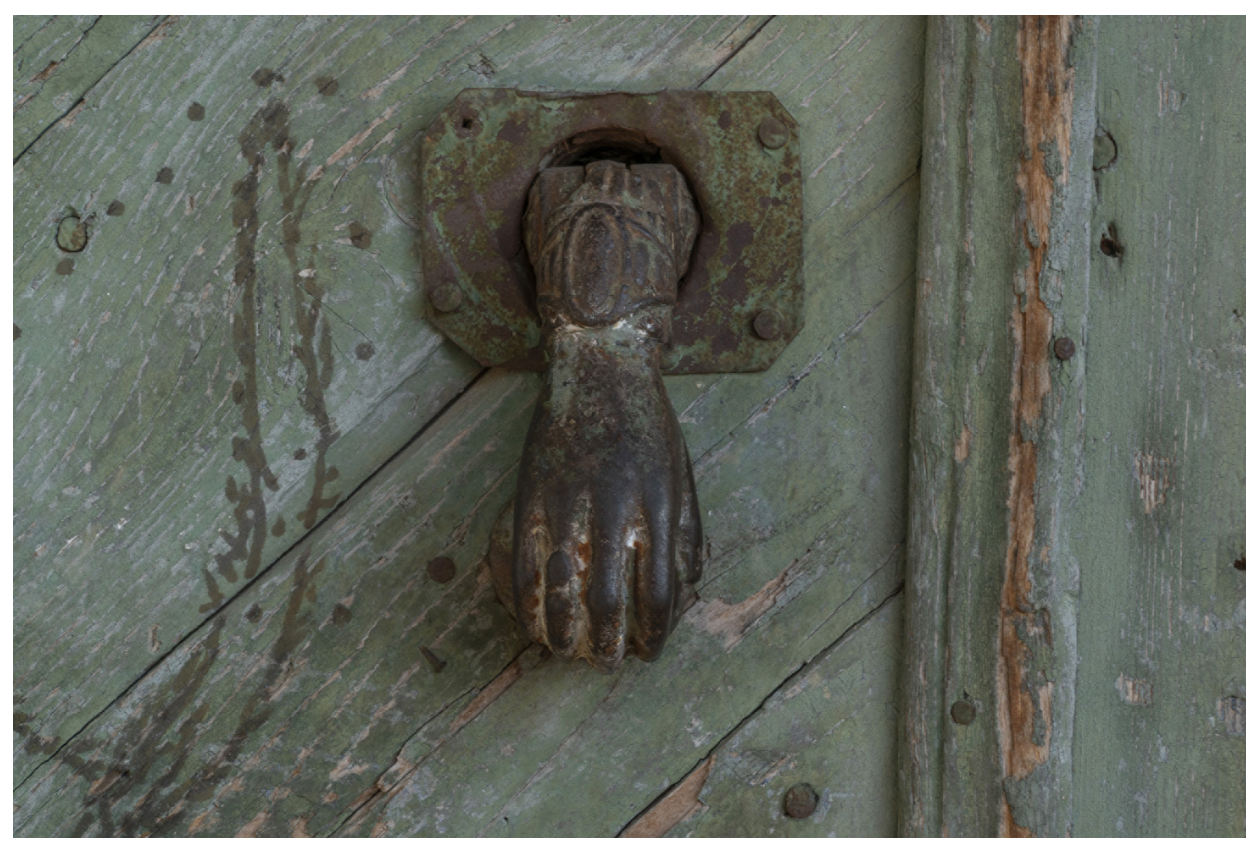




\section{I portali di Rehovë}

I portali di Rehovë risultano composti da un abaco di elementi ben definito: le spalle laterali, l'architrave, l'infisso, la copertura e i sedili.

La struttura lapidea che fiancheggia l'apertura è in opera a secco (raramente con fughe in malta o intonacata) e, talvolta, presenta una incisione con l'anno di costruzione (fig. 2). L'architrave che spesso poggia su mensole lapidee (fig. 3) è in legno dipinto in genere dello stesso colore del portale. La copertura tradizionale è a due falde sorrette da una struttura lignea e sormontate da un manto in lastre di pietra (fig. 4). L'infisso, in legno dipinto di verde o marrone, presenta spesso sull'anta destra un batti-porta realizzato in metallo con le sembianze di una mano (fig. 5). Completano il portale le panche in pietra, sedute incassate nello spessore murario che fiancheggia il portale (fig. 6), utili per la sosta sia del viandante che del visitatore.

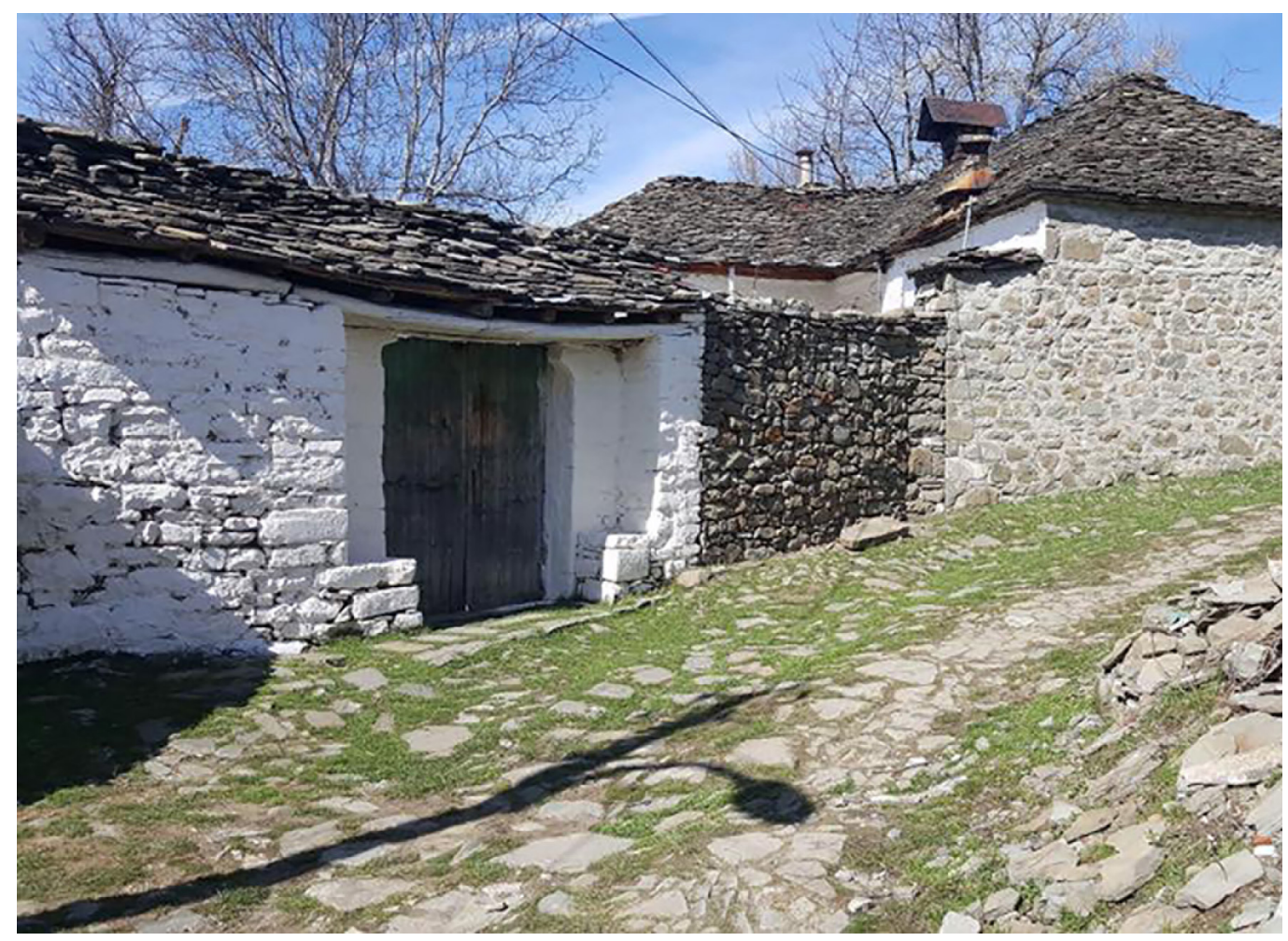

L'apparato figurativo presente sulle spalle dei portali rimanda al significato ancestrale della soglia: delimitare un dentro da un fuori, il noto dall'ignoto, l'ordine dal caos [I4]. Così appaiono coppie di leoni a guardia del confine (fig. 7), apparati floreali (tra cui rami d'ulivo) che decorano le spalle in pietra, una figura umana che afferra un serpente per il capo con la mano destra [I5] (fig. 8).

Nel microcosmo del villaggio, le diverse declinazioni del tipo, insieme al grado di manutenzione dei manufatti, definiscono le differenze sociali, economiche e culturali dei proprietari. Oggi molti dei manufatti sono stati modificati impropriamente: in numerosi portali il manto di copertura in pietra delle falde è stato sostituito con elementi in plastica (fig. 9), mentre in alcuni casi la copertura è state interamente ricostruita con una soletta piana in calcestruzzo armato (fig. I0); in circa un terzo degli infissi, infine, alle originali ante in legno sono state preferite nuove porte in metallo decorate a motivi geometrici e verniciate (fig. I I). 
Fig. 7. Mensola con un leone raffigurato (si tratt di una coppia di figure disposte una per lato)

Fig. 8. Incisione rappresentante una figura umana e un serpente.
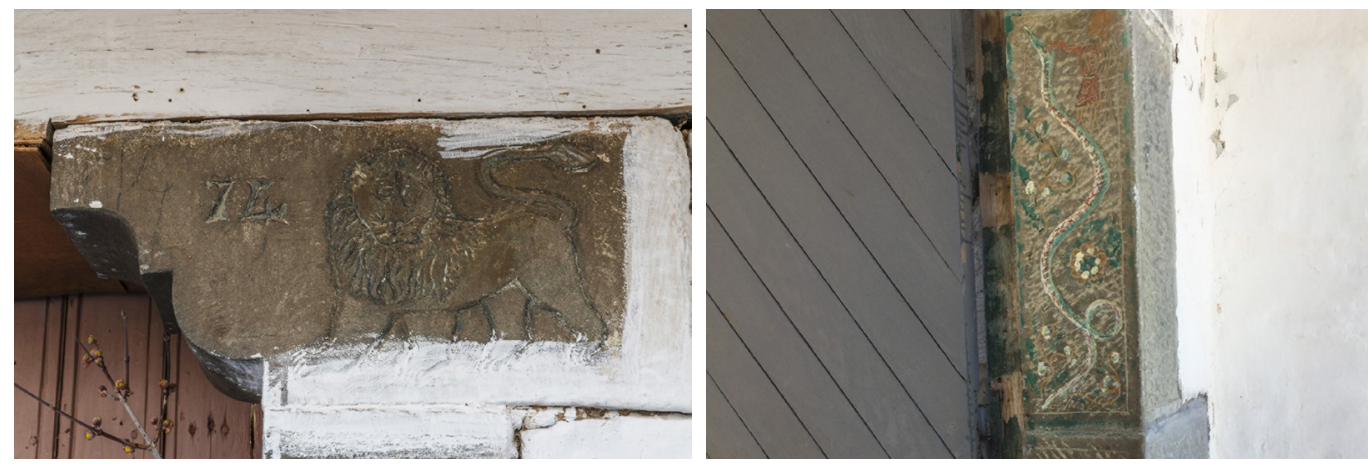

\section{Conclusioni}

La documentazione digitale ha consentito di mettere in evidenza sia forma e dimensione degli elementi che costituiscono i portali, sia il complessivo stato di degrado in cui versano, le cui cause sono ascrivibili non solo alla vetustà delle costruzioni, bensì agli interventi di sostituzione (con elementi e materiali incongrui) effettuati nel corso degli anni, che hanno contribuito alla perdita dei caratteri formali e materici originari [16].

È stata inoltre realizzata una mappa interattiva navigabile online [17] che consente di visionare le varie schede e i modelli tridimensionali di alcuni dei portali più significativi (meglio conservati o che presentano il maggior numero di elementi originari).

Un parallelo studio sul degrado, condotto dal prof. Michele Coppola (anch'egli docente presso l'Università Nostra Signora del Buon Consiglio di Tirana) consentirà alle istituzioni preposte di programmare i necessari interventi di restauro, finalizzati alla conservazione dei caratteri distintivi di queste peculiari architetture.

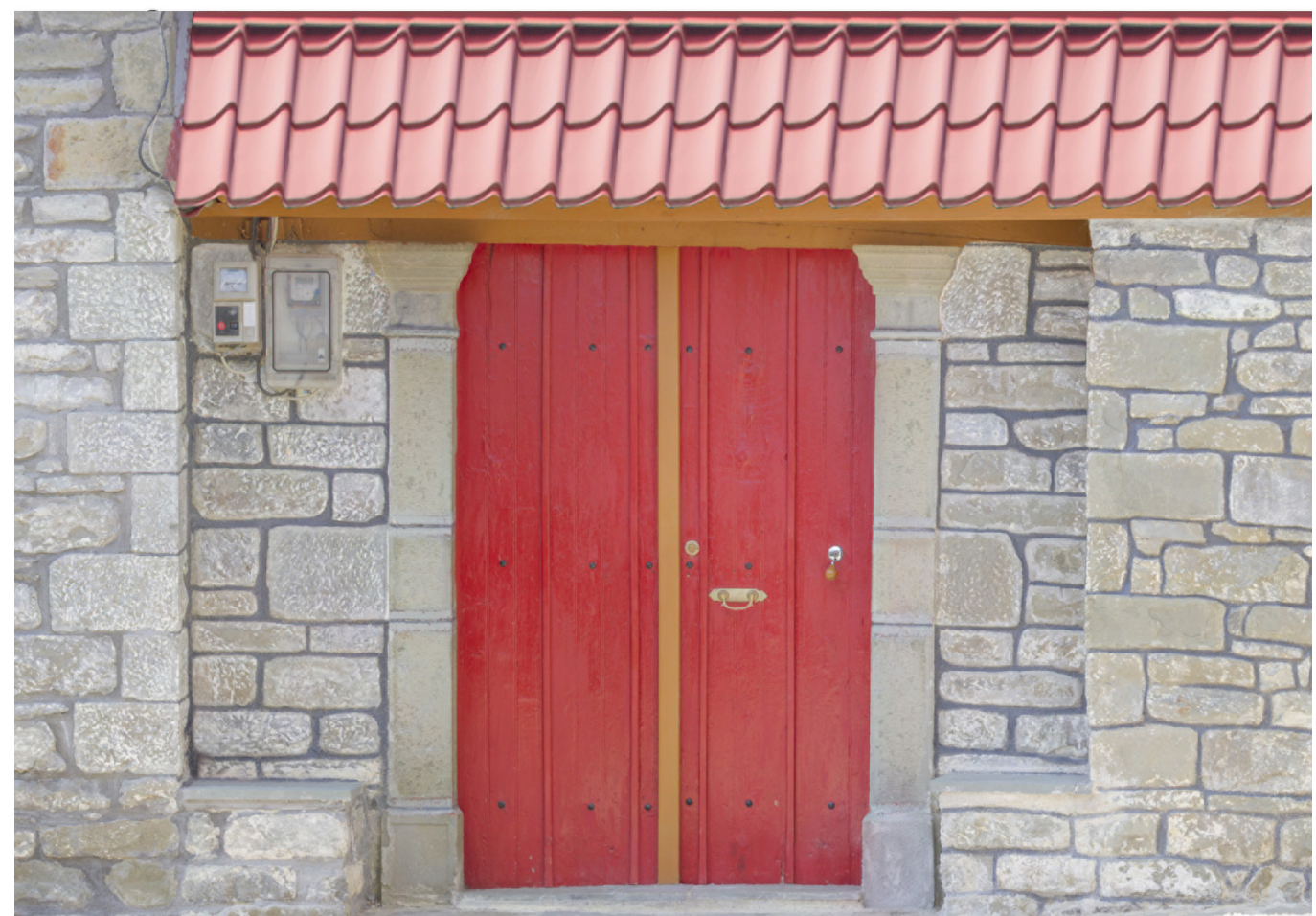


Fig. 10. Copertura tradizionale sostituita da una soletta in calcestruzzo armato.

Fig. I I. Infisso tradizionale sostituito da un infisso metallico.
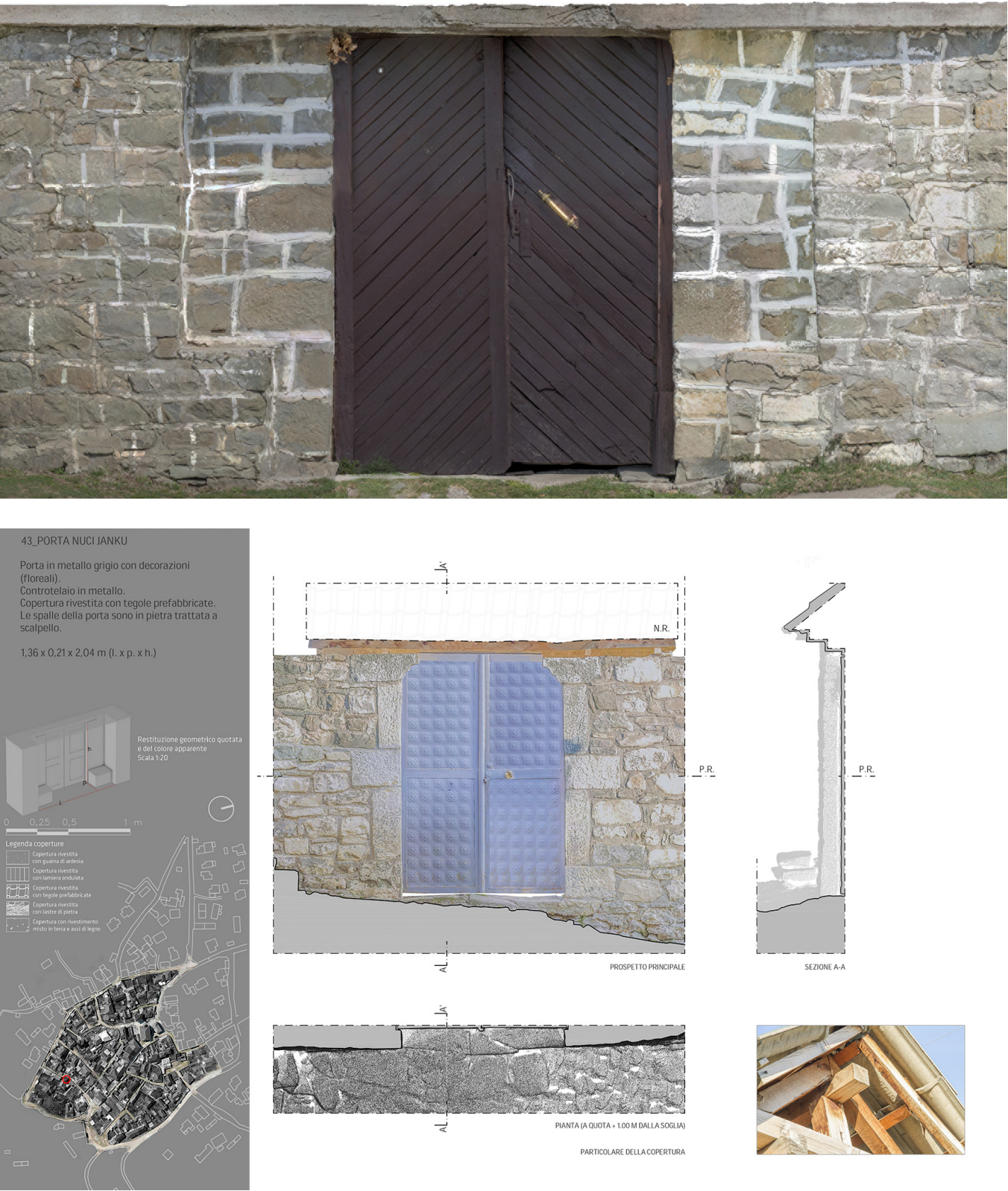

\section{Note}

[I] Si veda il tal senso il Progetto "I00 villaggi" sostenuto dal Primo Ministro Albanese Edi Rama; si tratta di un ampio progetto di documentazione e riqualificazione di alcuni insediamenti storici minori, facente parte del Programma di Sviluppo Rurale Integrato della Repubblica albanese.

[2] II gruppo di lavoro impegnato nel rilievo dei portali (responsabile scientifico prof. Alessandro Merlo) è composta da: Arch. Ph.D. Francesco Tioli, Arch. Giulia Lazzari, Arch. Francesco Frullini, Dott. Domenico Palattella.

[3] La proprietà delle abitazioni viene trasmessa esclusivamente all'interno della famiglia, estremamente rare le vendite (Cule Dhorjela, 20 17. Rehova, fshati ku turistët hanë bashkë me banorët. "TemA Online in Aktualitet, Kryesore, Sociale, Turizëm”.

[4] Nel 2013 l'Agenzia di promozione turistica Ecotour Albania, in collaborazione con Arinas-ER, organizzò un progetto di formazione per gli abitanti nell'ambito dell'accoglienza turistica.

[5] Si Veda: Braudel 2004, pp 36, 401.

[6] Si tratta comunque di tipologie abitative che si basano su un concetto simile, seppur declinato in maniera differente, in quanto "allo spazio pubblico, corrisponde lo spazio chiuso e privato della casa: generalmente la forma più comune è quella accentrata che testimonia la tendenza delle popolazioni rurali a raggrupparsi in comunità, con una organizzazione che ruota intorno al patio centrale, dove avvengono buona parte delle attività domestiche e si svolge la vita di relazione." (Cfr. Oliviero, 2014, p. 54) 
[7] La venerazione degli dei greci Hestia e Hermes si è trasformata in epoca romana nel culto domestico di Vesta (protettrice del focolare domestico) e Mercurio (protettore dei viaggiatori).

[8] Si veda: Bassanelli 2015, p. 521.

[9] Si veda: Ponti 1928, p. 7.

[10] Complessivamente sono state necessarie 290 scansioni per documentare i 68 portali individuati.

[I I] Laser scanner utilizzati: Z+F IMAGER@ 5016 e FARO FOCUSM 70.

[12] Macchine fotografiche utilizzate per la fotogrammetria terrestre: Canon 7D e Sony Alpha 7rll; fotogrammetria aerea: fotocamera incorporata nel drone DJI Spark.

[1 3] Sono stati prodotti: 68 sezioni orizzontali e altrettante verticali a fil di ferro; 75 fotopiani di cui 14 rappresentano l'interno e l'esterno dei medesimi infissi; I ortofoto in vista azimutale dell'intero villaggio.

[14] Si veda la simbologia del portale negli ambiti liturgici di molte religioni; parimenti, in ambito urbano, la porta di accesso aperta nelle mura è il significante del passaggio da una struttura sparsa, non definita, ad una organizzata e funzionale (Zizic Ivica, 20 17. Varcare la soglia. II simbolismo della porta. Antropologia - Liturgia - Cultura. Relazione a convegno (Bari). Roma: Pontificio Istituto Liturgico, 2017, p. 10).

[15] Rimanda alla leggenda di Asclepio diventato, una volta morto, la costellazione di Ofiuco, letteralmente "colui che porta il serpente"; posto all'ingresso di un'abitazione proteggerebbe dalle malattie.

[ 16] Solo a titolo di esempio: stuccatura di giunti realizzata con malte cementizie, installazione di contatori e relativi cavi sulle spalle dei portali, inserimento di elementi metallici non adeguatamente protetti contro il fenomeno della ruggine, etc.

[ 17]Visitabile dal link:<http://architettura3d.altervista.org/Maps_Rehove/index.html> (CHMLab, autore:Arch. Francesco Frullini).

\section{Riferimenti bibliografici}

Baculo Giusti Adriana (1996). Napoli al quattromila. Assonometria e pianta sinottica della città. Napoli: Electa.

Bassanelli Michela (20।5). Abitare la soglia. Penetrazioni negli spazi interstiziali della domesticità. Atti delle Giornate Internazionali di Studio $3^{\circ}$ Edizione di "Abitare il Futuro". Napoli: Clean, 20 I5, pp. 519-527.

Biagini Antonello (1998). Storia dell'Albania. Dalle origini ai giorni nostri. Milano: Bompiani.

Braudel Fernando (2004). Memorie del Mediterraneo. Preistoria e antichità. Milano: Bompiani. Ed. orig. Les Mémoires de la Méditerranée. Paris: Éditions de Fallois (1998).

Brondino Michele (20 I8). II Mediterraneo: mare della diversità e della condivisione. In Emina Antonella (a cura di). Territori e Scenari. Ripensare il Mediterraneo. Quaderni IRCrES-CNR. Torino: IRCRES-CNR.

Croatto Giorgio, Turrini Umberto, Shalsi Eranda (20 I 6). Così vicini così lontani. Architettura e tradizione in terra di Albania. Milano: Franco Angeli.

Firenze Architettura. La soglia, 2, (2012). online: <https://issuu.com/dida-unifi/docs/fa20 I2-2>.

Giovannini Massimo, Arena Marinella, Raffa Paola (a cura di). (20I5). Spazi e culture del Mediterraneo 4. Costruzione di un atlante del patrimonio culturale mediterraneo. Napoli: La scuola di Pitagora.

Manferdini Anna Maria, Russo Michele (20I5). Dal rilievo alle rappresentazioni ad alta risoluzione dello spazio architettonico continuo. II caso di studio del complesso dell'Abbazia di Pomposa. In DisegnareCon, Disegno per il Restauro: Oltre il Rilievo, pp l.I-I.

Ponti Giò (1928). La casa all'italiana. In Domus, I, p. 7.

Russo Michele (2019). Fotomodellazione 2020: viaggio di sola andata? In Belardi Paola (a cura di). Riflessioni/ Reflections. Atti del $41^{\circ}$ Convegno Internazionale dei Docenti della Rappresentazione. Perugia 19-21 settembre 2019. Roma: Gangemi, pp 997-1002.

Tucci Grazia et al., (2004). Metodi di rilievo tridimensionale a confronto: affidabilità metrica e capacità descrittive. In Atti del Convegno eArcom. Tecnologie per comunicare l'architettura. Ancona. pp 553-558.

\section{Autore}

Giulia Lazzari, Università degli Studi di Firenze, giulia.lazzari@unifi.it

Per citare questo capitolo: Lazzari Giulia (2020). I Varchi della memoria. La documentazione dei portali del villaggio Rehovë (Albania)/The Gate of Memory. The Documentation of the Village of Rehovë (Albania). In Arena A., Arena M., Brandolino R.G., Colistra D., Ginex G., Mediati D. Nucifora S., Raffa P. (a cura di). Connettere. Un disegno per annodare e tessere. Atti del $42^{\circ}$ Convegno Internazionale dei Docenti delle Discipline della Rappresentazione/Connecting. Drawing for weaving relationships. Proceedings of the 42 th International Conference of Representation Disciplines Teachers. Milano: FrancoAngeli, pp. 2344-2359. 


\section{The Gate of Memory. The Documentation of the Village of Rehovë (Albania)}

Giulia Lazzari

Abstract

In the south-east of Albania, on the slopes of Mount Gramoz on which the border with Northern Greece stands, the rural village of Rehovë is located. As often happens, it's possible to find the roots of a civilization, often entrusted to apparently insignificant material witness, in the heart of the most remote regions. In Rehovë, unknown stonemasons built the entire village using local limestone; the two-storey houses are located within quadrangular walls which, together with their gates, characterize the urban structure of the settlement. In 2019 the DIDA's CHMLab was entrusted with the morphometric and chromatic documentation of these artefacts aimed at their conservation.

Keyword

digital survey, photogrammetry, documentation, traditional architecture, threshold.

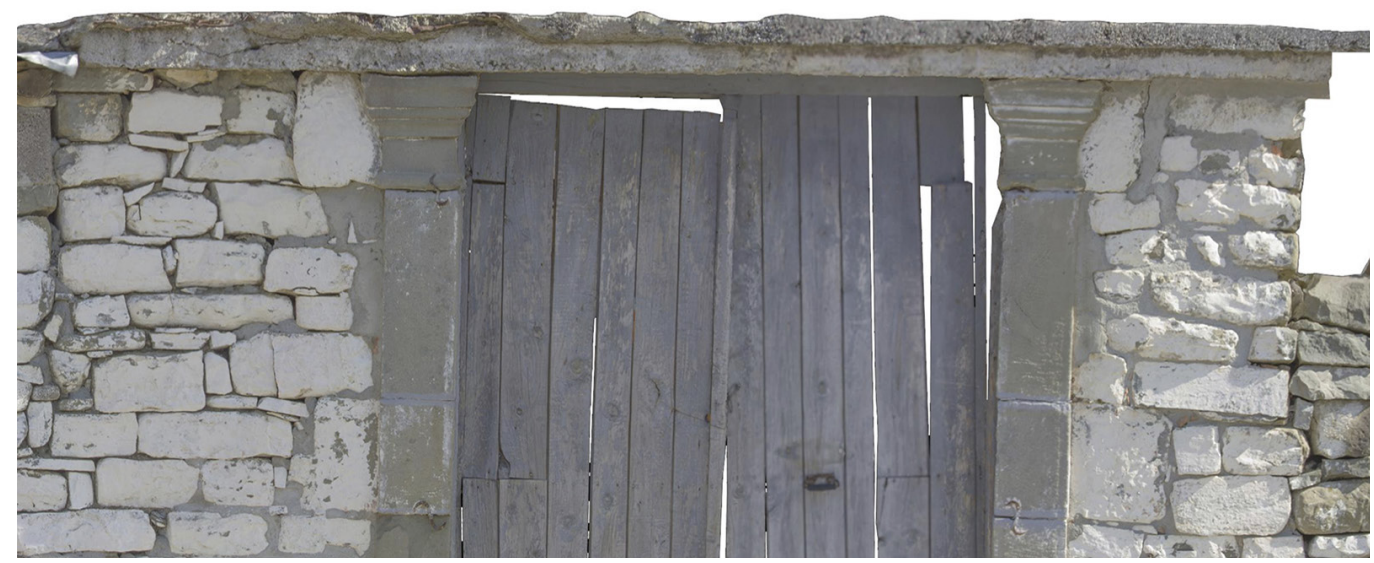




\section{Introduction}

The realization of the survey campaign carried out by the DIDA (Department of Architecture of the University of Florence) CHMLab (Cultural Heritage Management Lab) starts from the interest shown by the Ministry of Culture of the Albanian Republic towards the minor settlements, object from 2017 of an extensive historical-documental investigation [I]. In January 2017 Rehovë was awarded the title of "historical significance settlement" and a year later, together with the Catholic University of Our Lady of the Good Council of Tirana, the same Ministry requested the team [2] led by professor Alessandro Merlo (professor at the same University) to take over the sixty-eight gates present in the village. The purpose of the operation is to document the artefacts to preserve their original architectural characteristics which qualify the small settlement [3]. Already in 2016 Mirela Kumbaro, former Minister of Culture, had highlighted Rehovë's strategic role within tourism development policies in the Kolonjë region, proposing the route called The Routes of Gates [4].

The documentation obtained from the survey campaign was used not only to outline the geometric-dimensional consistency and the chromatic aspect of the gates with the aim of defining guidelines for their restoration, but also to make the local community aware on issues related to maintenance and conservation of its architectural and artistic heritage.

Fig. I. Porta Gjergji R. Qirjadi. Example of a data sheet containing plans, detailed photos.
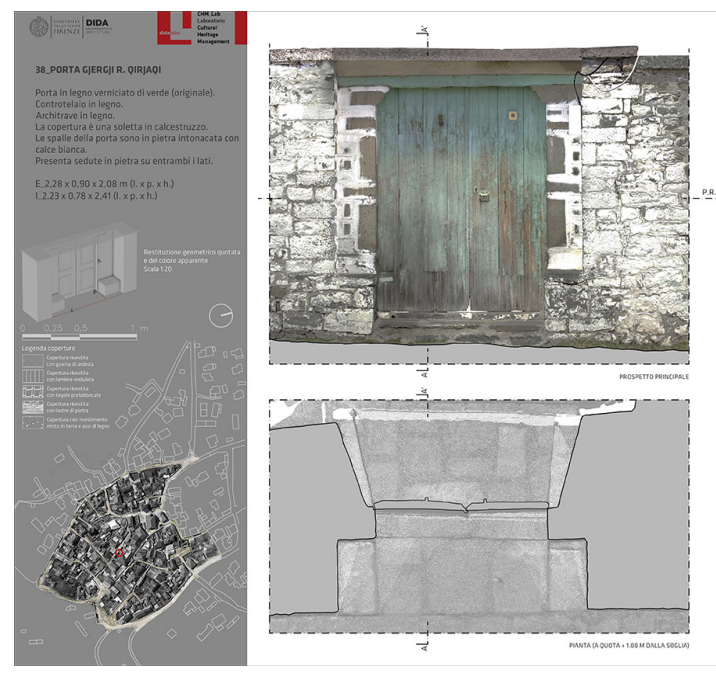
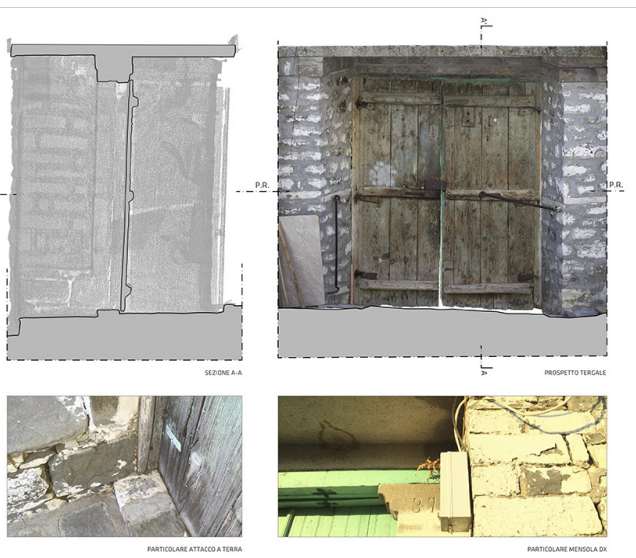

\section{The village of Rehovë}

The Mediterranean coasts are the cradle of millenary civilizations whose prosperity is largely due to the possibility of sailing, which has allowed them to weave economic and cultural networks over the centuries that have also mutually influenced the way of living [5].

In the specific case of the Balkans, the alternation on its coasts of two different cultures such as the Greek-Roman and the Turkish one has meant that both their housing archetypes [6] are still present in the territory: the 'domus', which embodies in home environments the fireplace of Hestia [7], and the 'court house', in which the rooms distributed around a central space are separated between men and women.

The urban system of the town of Rehovë consists of walled enclosures that define the quadrangular courtyards (most of which have similar dimensions of about 8x6 meters) in front of the houses, interrupted only by the presence of stone gates, which allow not only the passage from the public to private, but they constitute real places of relationship covered 
and shaded. In the recent past, passing through a gate had a ritual value here; crossing the threshold meant to get in touch with a microworld whose rules had to be accepted.

In the global world," contemporary social and economic influences have changed the classic anthropocentric model of the patriarchal family, causing changes in specific places of living: the limits are lost, and the internal / external, public / private borders become less clear" [8]. In the conception of the house in the West the clear distinction between interior and exterior has long been abandoned. Giò Ponti already in 1928, for example, described the Italian house as follows: "in the Italian house there is no great distinction of architecture between exterior and interior: elsewhere there is even separation of forms and materials: by us, the architecture of outside penetrates inside and does not neglect to use stone or plaster or fresco; it in the vestibules and galleries, in the rooms and in the stairways; it regulates and orders the rooms for our lives in wide spaces, with arches, niches, vaults and columns. From the inside, the Italian house comes outdoors with its porches and terraces, with pergolas and verandas, with loggias and balconies, roof terraces and belvederes, all very comfortable; these inventions for serene inhabiting are so much Italian that in every language are called by the Italian names" [9].

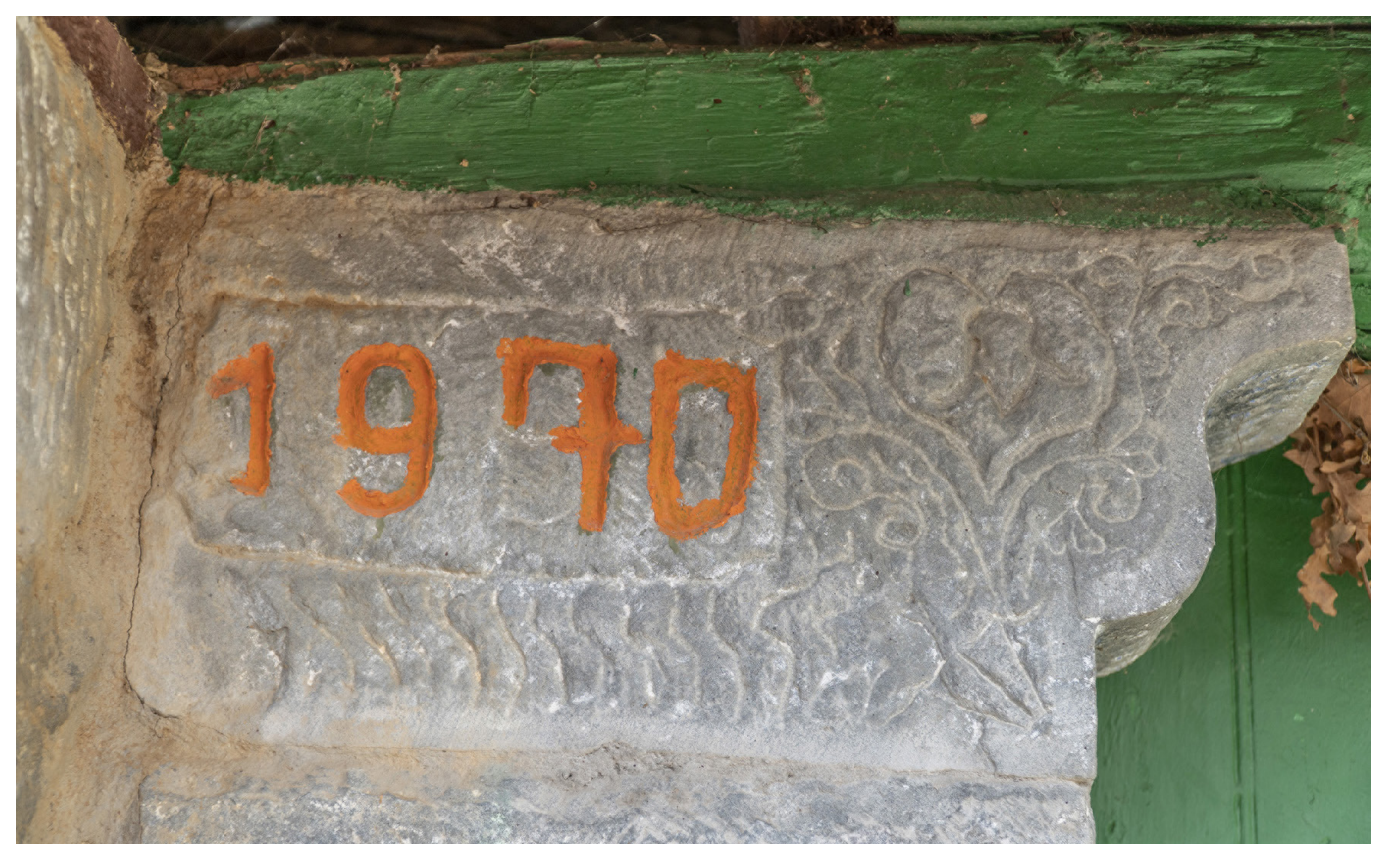

\section{Surveying and data restitution}

The survey campaign carried out in March 2019 allowed to acquire many geometric and chromatic information relating to the sixty-eight gates documented in the village of Rehovë. The measurement operations were conducted through the use of both active and passive digital sensors: the point clouds [I0], generated by two laser scanners [I I], allowed the creation of dense point clouds ( $139 \times 10^{7}$ points), capable of fully describing the morphology not only of the gates, but also of the streets of the village, while the apparent colour textures, deduced by photogrammetry [12], made it possible to create the orthophotos of the elevations, highlighting the decorations.

With the aim of geo-referencing the gates within the buildings, the artefacts were connected to each other by a series of intermediate scans, thus obtaining a 3D model of the 
Fig. 3. Wooden architrave resting of the stone corbel. Fig. 4. Roof cover made by stone slabs.
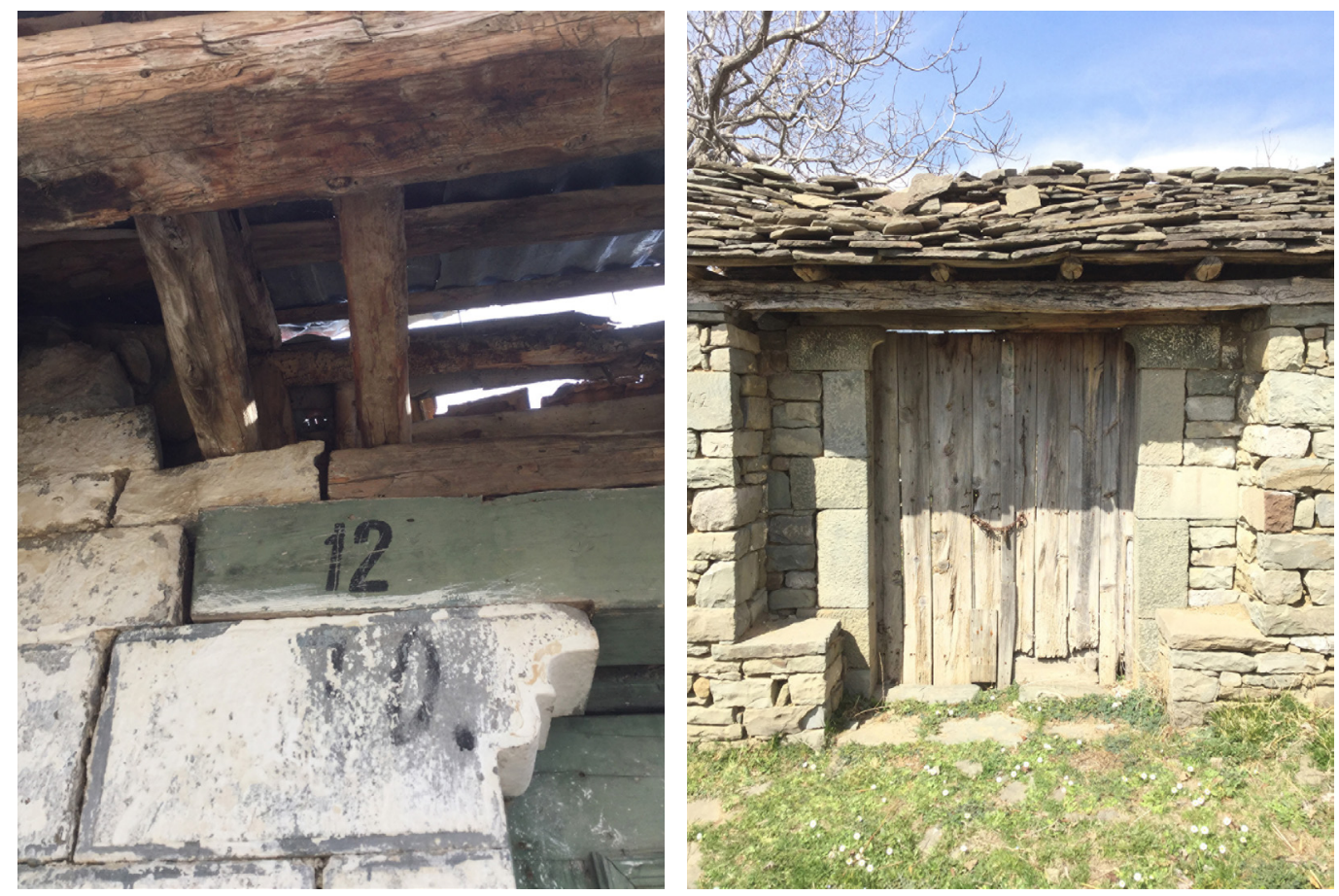

street system of the entire village with which it was possible, subsequently, to scale and roto-translate the photogrammetric model obtained from the images acquired both from the terrestrial and aerial photos.

A data sheet [13] of each artefact was subsequently produced, and it includes both the horizontal and vertical sections, the elevations with the information of the apparent colour (fig. I), the main dimensions and a short text that describes the artefacts highlighting the main characteristics.

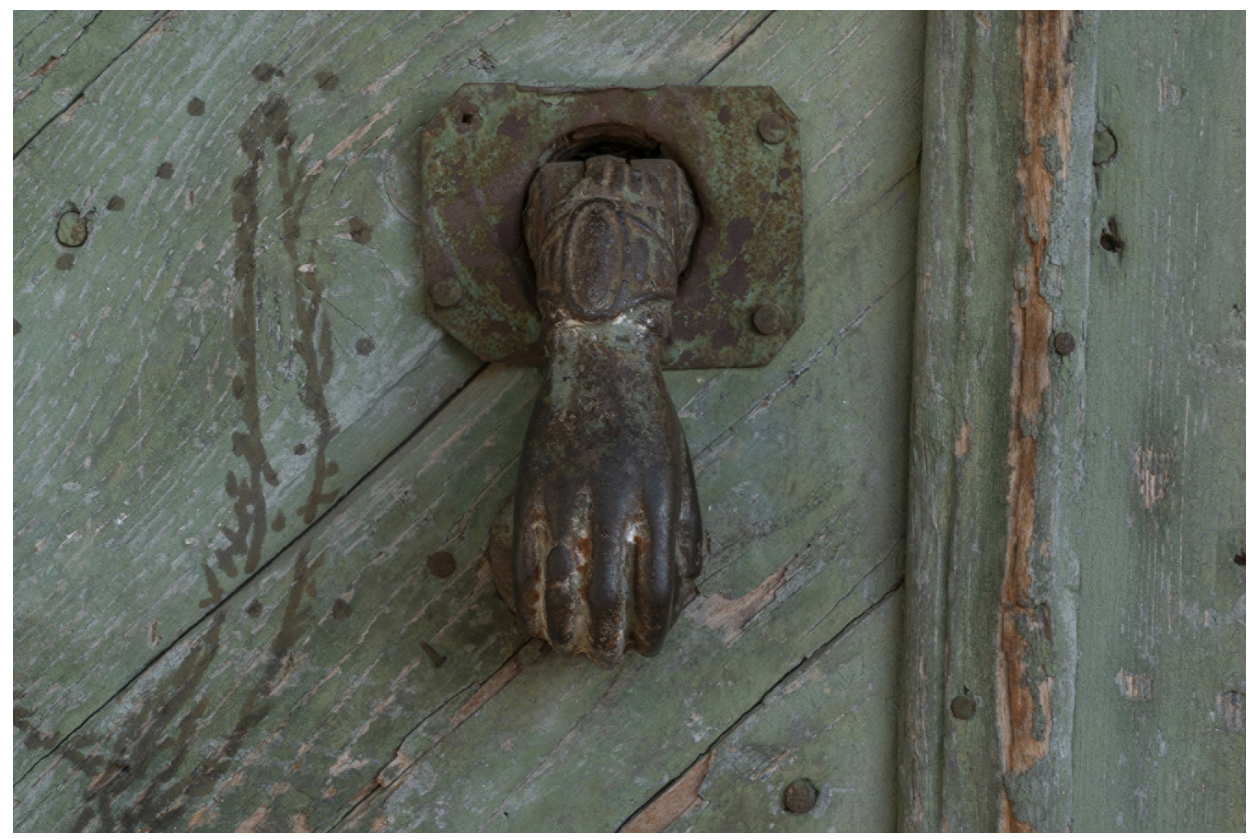

Fig. 5. Door knocker with the appearance of a close hand. 


\section{The portals of Rehovë}

The portals of Rehovë are composed of a well-defined abacus of elements: the lateral shoulders, the architrave, the door, the cover and the seats.

The stone structure flanking the passage is dry-laying (rarely with mortar or plaster joints) and sometimes has an incision with the year of construction (fig. 2). The architrave, that often rests on stone corbels (fig. 3), is in wood generally painted in the same colour as the door. The traditional roof has two pitches supported by a wooden structure and surmounted by stone slabs (fig. 4). The door, in green or brown painted wood, often has on the right leaf a door knocker made of metal with the appearance of a hand (fig. 5). The gate is completed by stone benches, seats recessed in the wall thickness that flanks the door (fig. 6), used for resting both the by traveller and by the visitor.

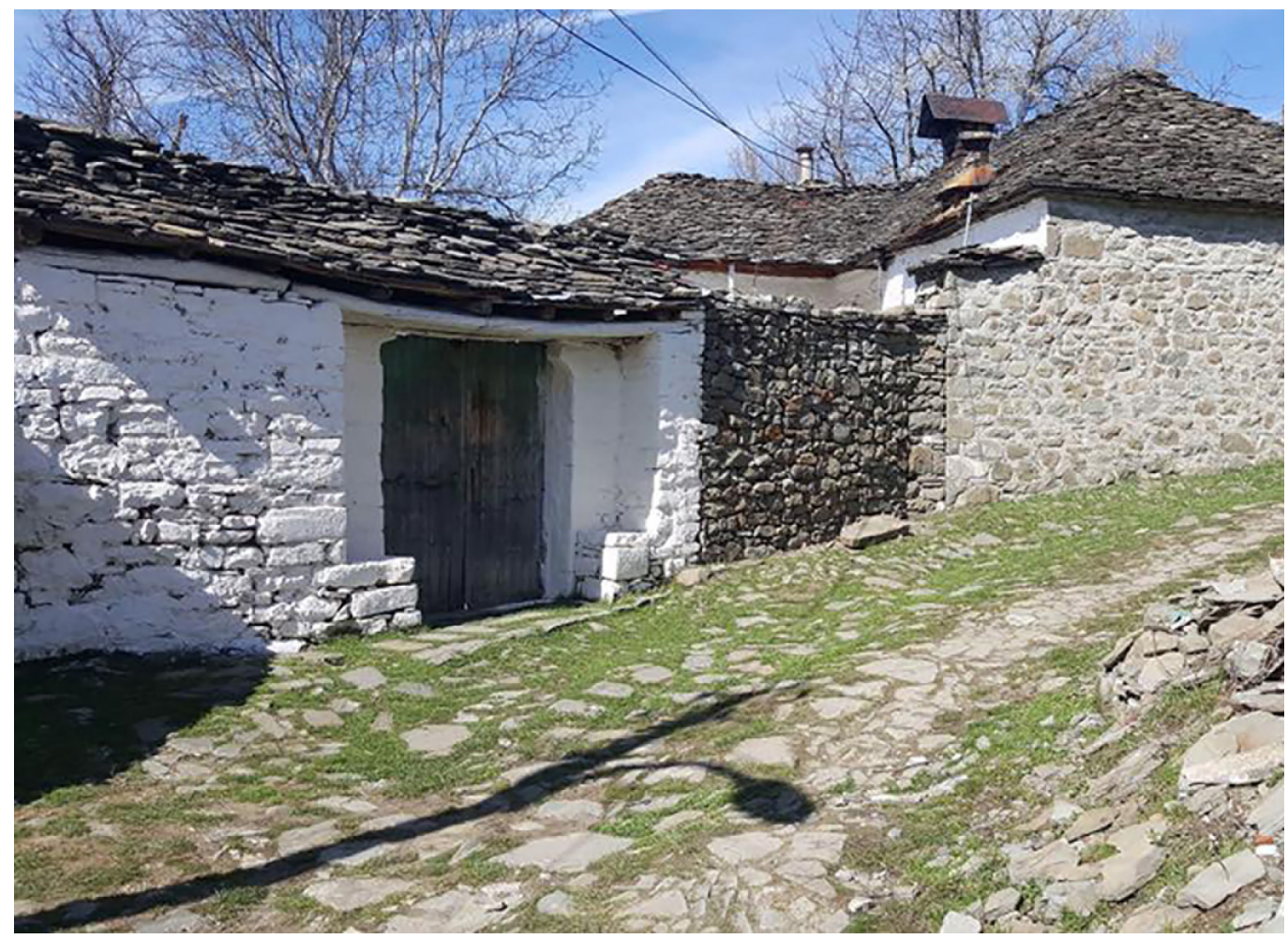

The figurative decoration standing on the lateral shoulders refers to the ancestral meaning of the threshold: delimiting an inside from an outside, the known from the unknown, the order from the chaos [14]. Thus, pairs of lions guarding the border appear (fig. 7), floral arrangements (including olive branches) decorate the stone shoulders, a human figure grasps a snake by the head with his right hand [I5] (fig. 8).

In the microcosm of the village, the different variations of the type, together with the maintenance status of the artefacts, define the social, economic and cultural differences of the owners.

Today many of the artefacts have been modified improperly: in numerous gates the stone roof slabs were replaced with plastic elements (fig. 9), while in some cases the roof was completely rebuilt with a flat slab in reinforced concrete (fig. I 0 ); finally, in about a third of the cases, new metal doors decorated with geometric and painted motifs were preferred to the original wooden doors (fig. I I). 
Fig. 7. Corbel with the incision of a lion (part of a pair of figures arranged one on each side)

Fig. 8. Incision representing a human figure and a snake.
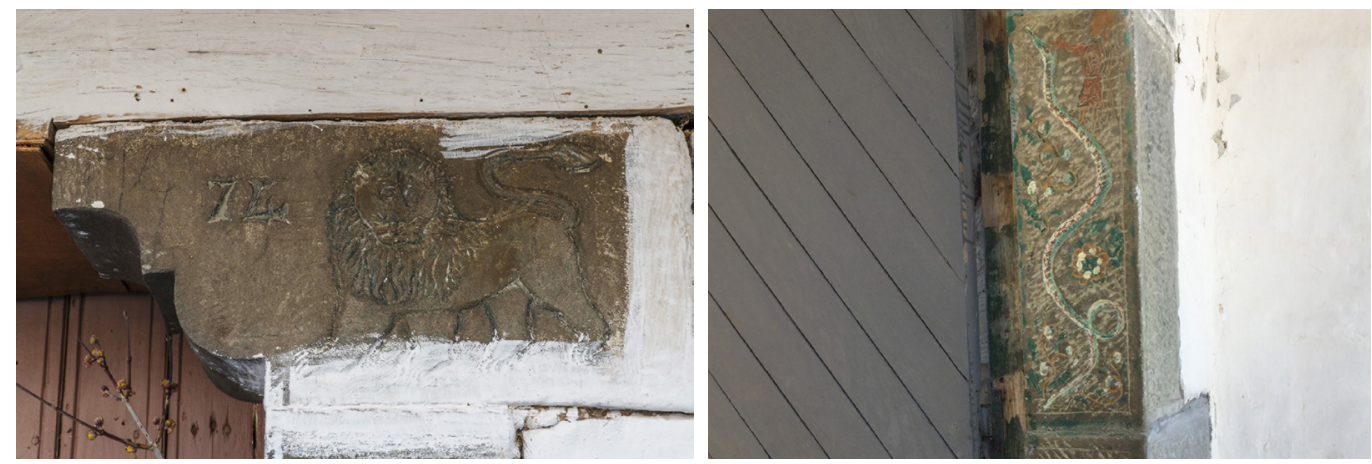

\section{Conclusions}

The digital documentation made possible to highlight both the shape and size of the elements of the gates, and their overall state of decay; the causes of this situation are attributable not only to the age of the buildings, but also to the replacement interventions (with incongruous elements and materials) carried out over the years, which contributed to the loss of the original formal and material characteristics [16].

An interactive navigable online [17] map has also been created; it allows to consult the various data sheets and three-dimensional models of some of the most significant gates (the best-preserved ones or those with the largest number of original elements).

A parallel study on decay, conducted by Prof. Michele Coppola (professor at the University of Our Lady of the Good Council of Tirana) will allow the institutions in charge to plan the necessary restoration interventions, aimed at preserving the distinctive characteristics of these peculiar architectures.

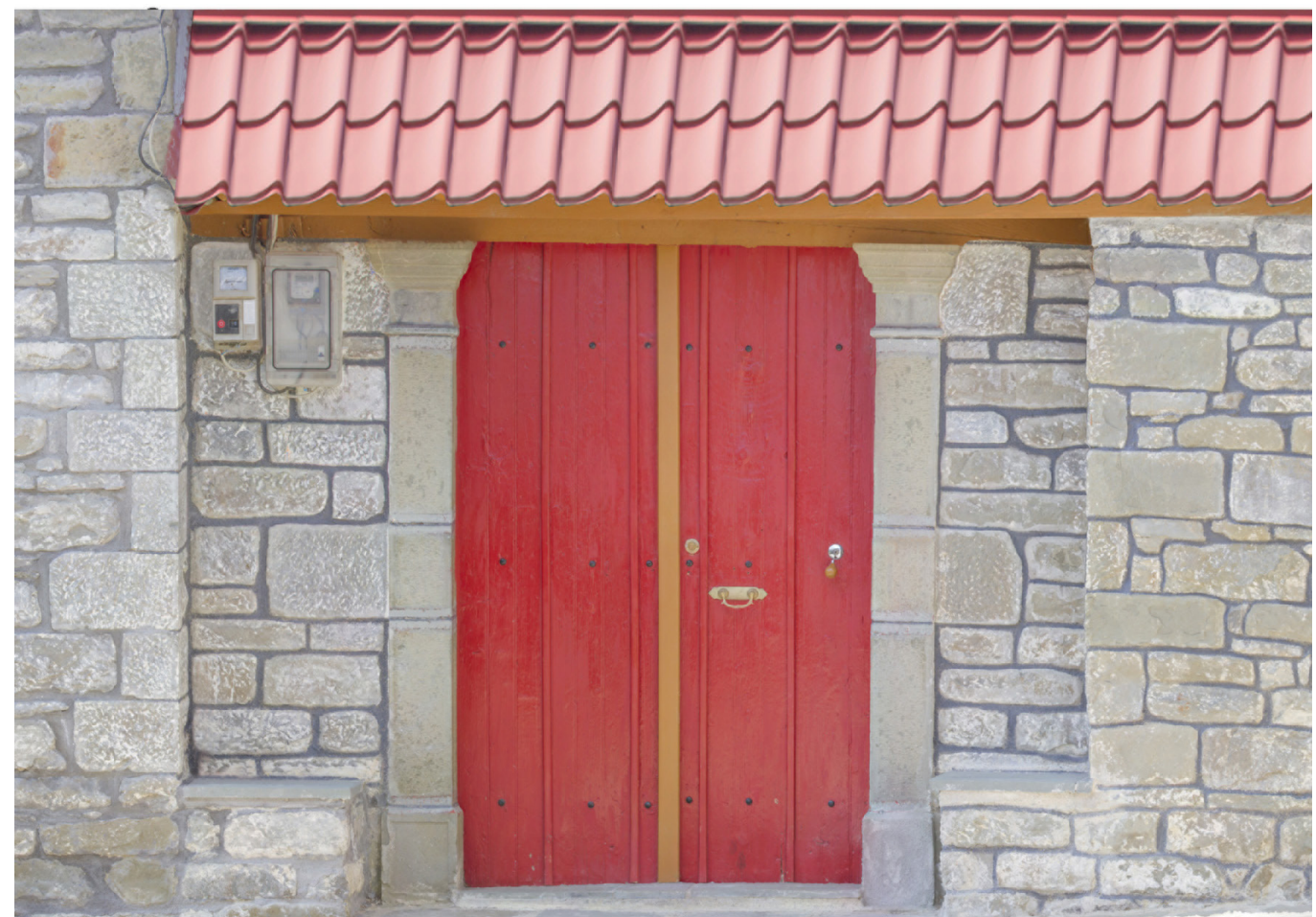


Fig. I 0.Traditional roof rebuilt with a flat slab in reinforced concrete.

Fig. I I.Traditional door replaced with new metal leaves.
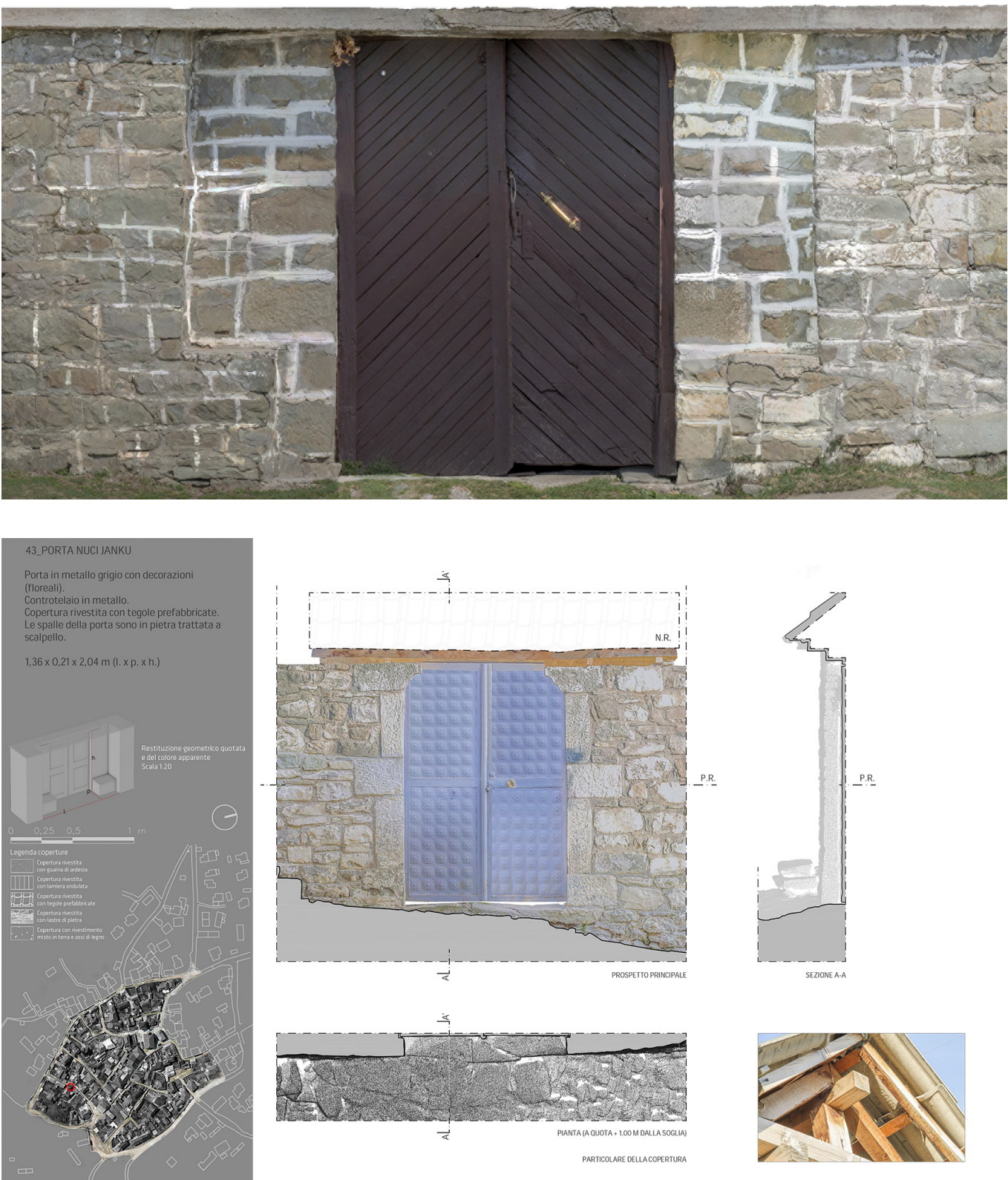

\section{Notes}

[I] See the "I 00 villages" project supported by Albanian Prime Minister Edi Rama; it is a large project of documentation and redevelopment of some minor historical settlements, part of the Integrated Rural Development Program of the Albanian Republic.

[2] The working group involved in the survey of the gates (Scientific Project Head Prof. Alessandro Merlo) is composed by Arch. Ph.D. Francesco Tioli, Arch. Giulia Lazzari, Arch. Francesco Frullini, Dr. Domenico Palattella.

[3] House ownership is transmitted exclusively within the family, sales are extremely rare (Cule Dhorjela, 20 I7. Rehova, fshati ku turistët hanë bashkë me banorët. «TemA Online in Aktualitet, Kryesore, Sociale,Turizëm" (last consultation: February 2020)

[4] In 2013, the tourism promotion Agency Ecotour Albania, in collaboration with Arinas-ER, organized a training project for the inhabitants in the field of tourist reception.

[5] See Braudel 2004, pp. 36, 401.

[6] However, these are housing typologies that are based on a similar concept, even if differently expressed, as "to the public space, corresponds to the closed and private space of the house: generally, the centralized disposition is the most common organization of the house and testifies the tendency of rural populations to gather in communities, with an organization that spreads around the central patio, where most of the domestic activities and the relationship life take place" - original quote: "allo spazio pubblico, corrisponde lo spazio chiuso e privato della casa: generalmente la forma più comune è quella accentrata che testimonia la tendenza delle popolazioni rurali a raggrupparsi in comunità, con una organizzazione che ruota intorno al patio centrale, dove awengono buona parte delle attività domestiche e si svolge la vita di relazione" [Oliviero 2014 , p. 54]. 
[7] The veneration of the Greek gods Hestia and Hermes was transformed in Roman Age into the domestic cult of Vesta (protector of the home fireplace) and Mercury (protector of travelers).

[8] See Bassanelli (20I5), p. 52 I [original quote: "le influenze sociali ed economiche della contemporaneità hanno modificato il modello antropocentrico classico della famiglia patriarcale determinando dei cambiamenti nei luoghi specifici dell'abitare: i limiti si perdono e i confini interno/esterno, pubblico/privato, diventano meno netti".

[9] See Ponti 1928, p. 7 - original quote: "nella casa all'italiana non vi è grande distinzione di architettura fra esterno ed interno: altrove vi è addirittura separazione di forme e di materiali: da noi l'architettura di fuori penetra nell'interno e non tralascia di usare né la pietra né gli intonaci né l'affresco; essa nei vestiboli e nelle gallerie, nelle stanze e nelle scale, con archi, nicchie, volte e con colonne regola e ordina in spaziose misure gli ambienti per la nostra vita. Dall'interno la casa all'italiana riesce all'aperto con i suoi portici e le sue terrazze, con le pergole e le verande, con le logge ed i balconi, le altane e i belvederi, invenzioni tutte confortevolissime per l'abitazione serena e tanto italiane che in ogni lingua sono chiamate con i nomi di quil".

[I0]The documentation of the 68 identified gates required 290 scans.

[I I] Laser scanners used: Z + F IMAGER尺 5016 and FARO FOCUS 70.

[12] Cameras used for terrestrial photogrammetry: Canon 7D and Sony Alpha 7rll; aerial photogrammetry: incorporated camera in the DJI Spark drone.

[13] The following drawings were produced: 68 horizontal and vertical sections; 75 orthophotos of which 14 represent the interior and exterior of the same door; I orthophoto in azimuthal view of the entire village.

[14] See the symbology of the portal in the liturgical context of many religions; likewise, in urban areas, the access door open through a wall is the signifier of the passage from a sparse, undefined structure to an organized and functional one (Zizic lvica, 2017. Varcare la soglia. II simbolismo della porta. Antropologia - Liturgia - Cultura. Relazione a convegno (Bari). Roma: Pontificio Istituto Liturgico, 2017, p. 10).

[15] It refers to the legend of Asclepius who, once dead, became the constellation of Ophiuchus, literally "the one who carries the snake"; placed at the entrance of a house would protect against disease.

[16] Just as an example: grouting joints made with cement mortars, installing counters and relative cables on the shoulders of the gates, inserting metal elements that are not adequately protected against the phenomenon of rust, etc.

[ I 7]Visible from the link: http://architettura3d.altervista.org/Maps_Rehove/index.html (CHMLab, author:Arch. Francesco Frullini).

\section{References}

Baculo Giusti Adriana (1996). Napoli al quattromila. Assonometria e pianta sinottica della città. Napoli: Electa.

Bassanelli Michela (20।5). Abitare la soglia. Penetrazioni negli spazi interstiziali della domesticità. Atti delle Giornate Internazionali di Studio $3^{\circ}$ Edizione di "Abitare il Futuro". Napoli: Clean, 20 I5, pp. 519-527.

Biagini Antonello (1998). Storia dell'Albania. Dalle origini ai giorni nostri. Milano: Bompiani.

Braudel Fernando (2004). Memorie del Mediterraneo. Preistoria e antichità. Milano: Bompiani. Ed. orig. Les Mémoires de la Méditerranée. Paris: Éditions de Fallois (1998).

Brondino Michele (20 18). II Mediterraneo: mare della diversità e della condivisione. In Emina Antonella (a cura di). Territori e Scenari. Ripensare il Mediterraneo. Quaderni IRCrES-CNR. Torino: IRCRES-CNR.

Croatto Giorgio, Turrini Umberto, Shalsi Eranda (2016). Così vicini così lontani. Architettura e tradizione in terra di Albania. Milano: Franco Angeli.

Firenze Architettura. La soglia, 2, (20 I2). online: <https://issuu.com/dida-unifi/docs/fa20 I2-2>.

Giovannini Massimo, Arena Marinella, Raffa Paola (a cura di). (20I5). Spazi e culture del Mediterraneo 4. Costruzione di un atlante del patrimonio culturale mediterraneo. Napoli: La scuola di Pitagora.

Manferdini Anna Maria, Russo Michele (20I5). Dal rilievo alle rappresentazioni ad alta risoluzione dello spazio architettonico continuo. II caso di studio del complesso dell'Abbazia di Pomposa. In DisegnareCon, Disegno per il Restauro: Oltre il Rilievo, pp l. I-I.

Ponti Giò (1928). La casa all'italiana. In Domus, I, p. 7.

Russo Michele (2019). Fotomodellazione 2020: viaggio di sola andata? In Belardi Paola (a cura di). Riflessioni/ Reflections. Atti del $41^{\circ}$ Convegno Internazionale dei Docenti della Rappresentazione. Perugia 19-21 settembre 2019. Roma: Gangemi, pp 997-1002.

Tucci Grazia et al., (2004). Metodi di rilievo tridimensionale a confronto: affidabilità metrica e capacità descrittive. In Atti del Convegno eArcom. Tecnologie per comunicare l'architettura. Ancona. pp 553-558.

\section{Author}

Giulia Lazzari, Università degli Studi di Firenze, giulia.lazzari@unifi.it

To cite this chapter. Lazzari Giulia (2020). IVarchi della memoria. La documentazione dei portali del villaggio Rehovë (Albania)/The Gate of Memory. The Documentation of the Village of Rehovë (Albania). In Arena A., Arena M., Brandolino R.G., Colistra D., Ginex G., Mediati D., Nucifora S. Raffa P. (a cura di). Connettere. Un disegno per annodare e tessere. Atti del $42^{\circ}$ Convegno Internazionale dei Docenti delle Discipline della Rappresentazione/Connecting. Drawing for weaving relationships. Proceedings of the 42th International Conference of Representation Disciplines Teachers. Milano: FrancoAngeli, pp. 2344-2359. 